\title{
Therapeutic Listening as a health intervention strategy: an integrative review
}

\author{
A ESCUTA TERAPÊUTICA COMO ESTRATÉGIA DE INTERVENÇÃO EM SAÚDE: UMA \\ REVISÃO INTEGRATIVA
}

\section{LA ESCUCHA TERAPÉUTICA COMO ESTRATEGIA DE INTERVENCIÓN EN SALUD: UNA REVISIÓN INTEGRADORA}

\section{Ana Cláudia Mesquita', Emilia Campos de Carvalho²}

\begin{abstract}
Objective: To investigate and evaluate the available evidence in the literature regarding the use of Therapeutic Listening as a health intervention strategy. Methods: Integrative review conducted on the following databases PubMed, CINAHL, The Cochrane Library, EMBASE, LILACS and APA PsycNET without restrictions of year or type of study. The keywords were combined in different ways to ensure extensive search of primary studies. Results: Among the 15 studies on Therapeutic Listening, $33 \%$ addressed the effect of training on listening skills, $27 \%$ focused on the efficacy of listening as an intervention, $20 \%$ explored the experiences lived by the subjects regarding listening and 20\% discussed various aspects of listening. Conclusion: Most studies have strong to moderate level of evidence, although addressing different aspects related to Therapeutic Listening, they have in common the need for recognition of skills on the part of health professionals, to develop an effective process of listening.
\end{abstract}

\section{DESCRIPTORS}

Interpersonal relations

Professional-patient relations

Communication

Patient care

Review.

\section{RESUMO}

Objetivo: Investigar e avaliar as evidências disponíveis na literatura a respeito do uso da Escuta Terapêutica como estratégia de intervenção em saúde. Método: Revisão integrativa, realizada nas bases de dados PubMed, CINAHL, The Cochrane Library, EMBASE, LILACS e APA PsycNET, sem restrições de ano ou tipo de estudo. Os descritores foram combinados de diferentes formas para garantir a busca ampla de estudos primários. Resultados: Dentre as 15 publicações sobre Escuta Terapêutica, 33\% abordaram o efeito de treinamentos sobre as habilidades de escuta, $27 \%$ estudaram a eficácia da escuta como intervenção, $20 \%$ exploraram as experiências dos sujeitos quanto às vivências relacionadas à escuta e $20 \%$ abordaram aspectos diversos da escuta. Conclusão: $\mathrm{A}$ maior parte dos estudos tem nível de evidência de forte a moderado e, apesar de abordarem diferentes aspectos relacionados à Escuta Terapêutica, apresentam em comum o reconhecimento da necessidade de habilidades, por parte do profissional de saúde, para o desenvolvimento de um processo de escuta eficaz.

\section{DESCRITORES}

Relações interpessoais

Relações profissional-paciente

Comunicação

Assistência ao paciente

Revisão

\section{RESUMEN}

Objetivo: Investigar y evaluar las evidencias disponibles en la literatura respecto del empleo de la Escucha Terapéutica como estrategia de intervención en salud. Método: Revisión integradora, llevada a cabo en las bases de datos PubMed, CINAHL, The Cochrane Library, EMBASE, LILACS y APA PsycNET, sin restricciones de año o tipo de estudio. Los descriptores fueron combinados de distintas maneras para asegurar la búsqueda amplia de estudios primarios. Resultados: Entre las 15 publicaciones sobre Escucha Terapéutica, el 33\% abordó el efecto de los entrenamientos relacionados con las habilidades de escucha, el $27 \%$ estudió la efectividad de la escucha como intervención, el 20\% exploró las experiencias de los sujetos en cuanto a las vivencias relacionadas con la escucha y el $20 \%$ abordó los aspectos diversos de la escucha. Conclusión: La mayor parte de los estudios tiene nivel de evidencia de fuerte a moderado y, a pesar de abordar los distintos aspectos relacionados con la Escucha Terapéutica, presentan en común el reconocimiento de la necesidad de habilidades, por parte del profesional de salud, para el desarrollo de un proceso de escucha eficaz.

\section{DESCRIPTORES}

Relaciones interpersonales

Relaciones profesional-paciente

Comunicación

Atención al paciente

Revisión

\footnotetext{
${ }^{1}$ Nurse. PhD student at the School of Nursing, Ribeirão Preto University of São Paulo. Ribeirão Preto, SP, Brazil. ${ }^{2}$ PhD in Nursing. Full professor, Ribeirão Preto University of São Paulo. Ribeirao Preto, SP, Brazil. 


\section{INTRODUCTION}

Researchers point to the need to develop interpersonal communication skills on the part of health professionals, so they can establish relationships that provide benefits to patients and their family members ${ }^{(1)}$. In a research conducted by nurses about emotional support in palliative care, it was concluded that the appropriate use of communication skills is the basis of emotional care of the individual and family experiencing psychological and emotional stress ${ }^{(2)}$. In another study conducted with the objective of understanding how women undergoing cancer chemotherapy perceive nursing care, the researchers found that the way patients reported perceiving the care provided by nursing exceeds the dimensions of technical procedures and favors the establishment of a care relationship facing the disease $\mathrm{e}^{(3)}$.

In this context, the listening is presented as a strategy of essential communication for understanding the other person, it is a positive attitude of warmth, interest and respect, therefore, being considered therapeutic ${ }^{(4)}$. In the literature, some expressions are used to name listening as a therapeutic process: active listening ${ }^{(5)}$, Full or attentive listening ${ }^{(6)}$, reflectively listening ${ }^{(7)}$, comprehensive listening ${ }^{(8)}$, actively listening ${ }^{(9)}$ and therapeutic listening ${ }^{(5)}$, term adopted for this review. Therapeutic Listening can be defined as a method of responding to others in order to encourage better communication and clearer understanding of personal concerns. It is an active and dynamic event that requires effort on the part of the listener to identify the verbal and nonverbal aspects of communication ${ }^{(10)}$.

From the Person Centered Model, developed by Carl Rogers, the use of listening happens to value the person as a subject who seeks and is able to develop him/herself ${ }^{(11)}$. Therapeutic Listening is appreciated by various psychological approaches and common sense, representing the basis of all responses effectively generating assistance ${ }^{(12)}$. In care, listening can minimize the anguish and alleviate the assisted suffering, because through a dialogue that is developed, it enables the individual to hear what he/she is saying, inducing him/her to a selfreflection ${ }^{(13)}$. The practice of listening means recognition of the patient suffering, because the act of listening assumes that there is something to listen to, offering them the opportunity to speak and express themselves ${ }^{(14)}$. Besides that, listening is an important tool for obtaining information, for example, through the use of open questions, summaries and clarification ${ }^{(7)}$.

However, although health professionals admit that the communication process is an important factor in the care provided ${ }^{(15)}$ and that listening is an essential skill when dealing with the patient ${ }^{(16)}$, the knowledge of communication strategies are scarce ${ }^{(15)}$. Thus, it becomes necessary to be deep in further reflection on listening as a therapeutic tool, so that it is not used indefinitely and without purpose ${ }^{(17)}$.

Considering that, even though its value is generally recognized, Therapeutic Listening has not been studied in depth $^{(14)}$, the national literature lacks studies that address such intervention and its importance as a prerequisite for a successful health meeting - with potential therapeutic value, especially in situations in which no specific medical intervention is required ${ }^{(14)}$ so, we pondered doing this integrative review from the following question: What are the available evidence in the literature regarding the use of Therapeutic Listening as a health intervention strategy? It is expected that nurses and other health professionals may improve their knowledge about this technique of interpersonal communication, as the professional-patient interaction to transmit attention, compassion and comfort is considered important ${ }^{(15)}$.

The present study aimed to investigate and evaluate the available evidence in the literature regarding the use of therapeutic listening as a health intervention strategy.

\section{METHODS}

This study is an integrative review, which since the 1980s have been published in the literature as a research method $^{(18)}$. The integrative review can be understood as an exhaustive systematic research of the scientific literature for the purpose of, from existing studies, presenting a comprehensive view of complex concepts, theories or important health problems ${ }^{(19)}$. It is noteworthy that the integrative review is one of the research methods used in Evidence Based Practice, which allows the incorporation of evidence into clinical practice, reinforcing the importance of research in health care ${ }^{(20)}$.

The steps for the development of this review were: development of the research question; search for primary studies in the databases; data extraction of the studies; critical appraisal of selected studies; analysis and synthesis of the results and presentation of re$v^{v i e w}{ }^{(19)}$. The guiding question of this review was: What are the available evidence in the literature regarding the use of Therapeutic Listening as an intervention strategy in health?

The data collection for this review was conducted in December 2013. For the selection of the studies, electronic searches were conducted in the following databases: US National Library of Medicine (PubMed), Cumulative Index to Nursing and Allied Health Literature (CINAHL), The Cochrane Library, Excerpta Medica Database (EMBASE), Latin American and Caribbean Literature on Health Sciences (LILACS) and American Psychological Association (APA PsycNET). To search for studies, controlled and not controlled descriptors were used, according to the indexing terms in each specific database (Chart 1 ). 
Chart 1 - Controlled and not controlled descriptors according to selected databases - Ribeirão Preto, SP, Brazil, 2013

\begin{tabular}{|l|c|c|}
\hline Databases & Controlled descriptors & Uncontrolled descriptors \\
\hline PubMed & - & Attentive listening; Therapeutic listening; Active listening; Listening Visits \\
\hline CINAHL & Active listening & Attentive listening; Therapeutic listening; Listening Visits \\
\hline COCHRANE & - & Attentive listening; Therapeutic listening; Active listening; Listening Visits \\
\hline EMBASE & - & Attentive listening; Therapeutic listening; Active listening; Listening Visits \\
\hline LILACS & $\begin{array}{c}\text { Escuta-acolhimento- } \\
\text { vinculo; Escuta/fala/ } \\
\text { reflexão }\end{array}$ & $\begin{array}{c}\text { Escuta Terapêtica; Escuta ativa; Escuta integral; Escuta atenta; Escuta compreensiva; Ouvir } \\
\text { ativamente; Ouvir efetivamente }\end{array}$ \\
\hline APA PsycNET & Listening (Interpersonal) & Attentive listening; Therapeutic listening; Active listening; Listening Visits \\
\hline
\end{tabular}

The inclusion criteria delimited to studies pre-selection were: primary studies in English, Portuguese or Spanish, published in journals that addressed therapeutic listening, not being established limit to the year or type of publication. The process of study selection was performed through the careful reading of titles and abstracts, in a way that followed to be included the studies that met the inclusion criteria above. The studies without abstracts were obtained in full for further detailed analysis and delineation of their eligibility. For the final selection of the studies, a full reading of the study was performed, to make sure that those selected had Therapeutic Listening as a central focus of the study.

To collect and analyze the data, we used a validated instrument ${ }^{(21)}$, which was adapted to meet the study objective. The instrument contained variables to answer the guiding question of the study, so the topics of interest were: study title, authors, publication year, study setting, journal, objective, method, population/ sample, results, method of therapeutic listening use and level of evidence.

\section{RESULTS}

The final sample consisted of 15 publications (Table 1) from international journals in the field of health, being the oldest one published in 1955 and the latest one in 2013. Chart 2 presents a synthesis of the studies included in this review.

Table 1 - Distribution of publication selection of databases according to the inclusion criteria - Ribeirao Preto, SP, Brazil, 2013

\begin{tabular}{lccc}
\hline Databases & Result from search & Pre-included & Included \\
\hline PUBMED & 306 & 26 & 6 \\
CINAHL & 86 & 18 & 2 \\
COCHRANE & 20 & 4 & 0 \\
EMBASE & 135 & 7 & 2 \\
LILACS & 41 & 3 & 0 \\
APA PsycNET & 1104 & 16 & 5 \\
\hline Total & $\mathbf{1 6 9 1}$ & $\mathbf{7 3}$ & $\mathbf{1 5}$ \\
\hline
\end{tabular}

Chart 2 - Summary box of the characteristics of the included studies in the review according to the objective, methodology and main results - Ribeirao Preto, SP, Brazil, 2013

\begin{tabular}{|c|c|c|c|}
\hline Study & Objective & Methodology & Main results \\
\hline $\mathrm{A} 1^{(22)}$ & $\begin{array}{l}\text { To observe if previous informa- } \\
\text { tion about the patient can influ- } \\
\text { ence the process of Therapeutic } \\
\text { Listening performed by students } \\
\text { and professionals of psychology. }\end{array}$ & $\begin{array}{l}\text { Quasi-experimental study }(\mathrm{n}=19) \text {. One part of } \\
\text { the subjects received only the instructions for } \\
\text { participation in the study, while the other half also } \\
\text { received information about the patient. }\end{array}$ & $\begin{array}{l}\text { Prior clinical information produced no sig- } \\
\text { nificant difference }(0.01<p<0.05)\end{array}$ \\
\hline $\mathrm{A} 2^{(23)}$ & $\begin{array}{l}\text { To investigate the effects of train- } \\
\text { ing on the skills of Therapeutic } \\
\text { Listening of nursing students. }\end{array}$ & $\begin{array}{l}\text { Quasi-experimental study ( } \mathrm{n}=26) \text {. Training offering } \\
\text { on communication with duration of } 42 \text { hours }(6 \\
\text { hours exclusively dedicated to Therapeutic Listen). }\end{array}$ & $\begin{array}{l}\text { There was an increase on Therapeutic Listen- } \\
\text { ing skills }(\mathrm{p}<0.0005) \text { and reduced difficulty } \\
\text { of identifying the feelings of the respondent } \\
\qquad(\mathrm{p}<0.005) \text {. }\end{array}$ \\
\hline $\mathrm{A} 3^{(24)}$ & $\begin{array}{l}\text { To investigate the effect of two } \\
\text { types of Therapeutic Listening } \\
\text { responses about the emotional } \\
\text { reactions of patients. }\end{array}$ & $\begin{array}{l}\text { Experimental study ( } \mathrm{n}=55) \text {. The subjects were } \\
\text { divided into groups. Randomized, one would play } \\
\text { the role of the patient, another the therapist and } \\
\text { the other would observe the interaction. Orienta- } \\
\text { tions were offered to "Patient" and "therapist" on } \\
\text { the context of the situation being simulated. The } \\
\text { "therapist" was asked about the type of answer } \\
\text { that should be used in interaction }\end{array}$ & $\begin{array}{l}\text { When using responses that allow alternative } \\
\text { interpretations to the interpretation that the } \\
\text { patient makes of the situation, this may pres- } \\
\text { ent less intense levels of anger }(\mathrm{p}<0.0001) \\
\text { and depression }(\mathrm{p}=0.0105) \text {. }\end{array}$ \\
\hline $\mathrm{A} 4^{(25)}$ & $\begin{array}{l}\text { To evaluate the effectiveness } \\
\text { of different training modes on } \\
\text { Therapeutic Listening offered to } \\
\text { undergraduates. }\end{array}$ & $\begin{array}{l}\text { Experimental and Quasi-Experimental study } \\
(\mathrm{n}=30) \text {. Participants were divided into three } \\
\text { groups with different types of training on Thera- } \\
\text { peutic Listening. }\end{array}$ & $\begin{array}{l}\text { The drama group used approximately twice } \\
\text { as much answers than therapeutic Listening } \\
\text { group without training }(\mathrm{p}<0.05) \text {. }\end{array}$ \\
\hline
\end{tabular}




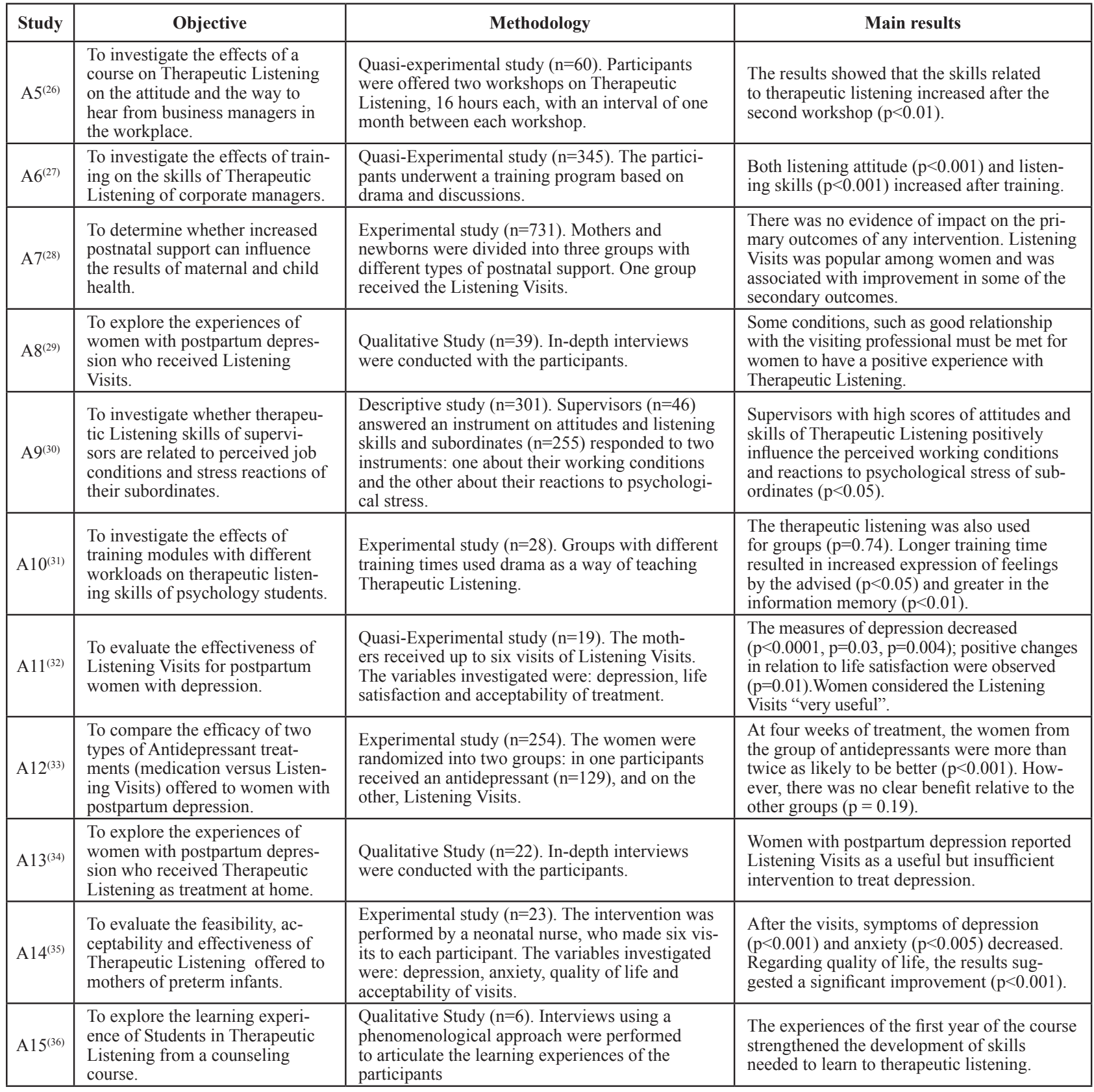

Among the included studies, seven (47\%) are from journals related to the field of Psychology/Psychotherapy (A1, A4, A8, A10, A11, A13 and A15), three (20\%) are from the area of Occupational Health (A5, $A 6$ and $A 9)$, one (7\%) from the area of Nursing Education (A2), two (13\%) from the area of Health Technology (A7 and A12) and two $(13 \%)$ are from journals of Social Service (A3) Maternal and Child Health (A14) (Box 2). As to the origin of the studies, five (33\%) were undertaken in the UK, four $(27 \%)$ in the United States, three $(20 \%)$ in Japan, two (13\%) in Sweden and one (7\%) in Canada.

As shown in Box 2, the most common study designs were experimental and quasi-experimental, with five publications each. It is noteworthy that, for this review, it is understood as experimental studies those with random allocation of subjects in experimental and control groups considering the exposure factor of interest by the investigator; quasi-experimental studies are very similar to the experimental studies, however, they do not have characteristics of randomization and/or control group ${ }^{(37)}$.

Considering level of evidence, we used the classification suggested by Melnyk and Fineout-Overholt(38), which classifies the studies, from experimental design in seven levels: 1- systematic review or meta-analysis of randomized controlled clinical trials; 2-: evidence from at least one randomized controlled trial well designed; 
3- Evidence obtained from well-designed no-randomized clinical trials; 4- Evidence originated from well-designed cohort and case-control studies; 5- Evidence originated from systematic review of descriptive and qualitative studies; 6- Evidence derived from a single descriptive or qualitative study; 7- Evidence from opinion of authorities and/or committees of experts report. Most of the publications (40\%) showed evidence level 2 (A3, A4, A7, A10, A12 and $A 14$ ), followed by $33 \%$ with evidence level 3 ( $A 1, A 2$, $A 5, A 6$ and $A 11$ ) and $27 \%$ with evidence level 6 (A8, A9, $\mathrm{A} 13$ and A15). Given this classification, the levels 1 and 2 are considered strong, 3 and 4 moderate and 5 to 7 weak evidences $^{(38)}$, in other words $40 \%$ of studies have strong evidence level, $33 \%$ moderate and $27 \%$ weak.

Most studies (33\%) addressed the effect of training on the Therapeutic Listening skills (A2, A4, A5, A6 and $A 10)$. The study $A 2^{(23)}$, before being subjected to a training module on communication, students answered an instrument that assesses the interpersonal skills of professionals or students of health to conduct interviews. The training lasted 42 hours, so that six hours were dedicated exclusively to therapeutic listening. After training, participants completed the instrument again. In the pre-training $30.4 \%$ of students identified feelings of participants, while in the post-training the percentage was $78.5 \%(p<0.0005)$. The content of the messages was identified in $57 \%$ of the situations before training and in $78.8 \%$ of the cases $(p<0.0005)$. Still, in the pre-training $6.4 \%$ of students were unable to identify the feelings of participants, while in the post-training this rate was reduced to $1.6 \%(p<0.005)$.

The study $\mathrm{A}^{(25)}$ different modes of Therapeutic Listening training were evaluated in an experimental and a quasi-experimental study. Twelve subjects participated in the experimental study, this group had supervised dramatization training, written exercises and discussion. Another twelve subjects participated in the quasi-experimental study that used supervised dramatization. The third group received no training and had no prior knowledge about the Therapeutic Listening $(n=6)$. In order to assess them, all participants had a consultation and counseling of seven minutes with the participation of a fictitious patient. The result was that in 6 of the 10 categories of the instrument used to assess students' skills, the drama group used approximately twice the Therapeutic Listening answers than the untrained group $(p<0.05)$.

The study $A 5^{(26)}$ consisted of two workshops on Therapeutic Listening of sixteen hours each, which were divided into two days, with an interval of one month between each workshop. The course was taught by business managers through lectures, discussions and practical activities. These activities were part of a training program in mental health. Participants completed an instrument, formulated by the authors of the study, which measured the effects of training on skills related to therapeutic listening, early at the beginning of the first and at the end of the second workshop. The results showed that the mean scores of the instrument increased significantly after the second workshop $(p<0.01)$.

The study $A 6^{(27)}$ was about a training program for Therapeutic Listening based on dramatizations and discussions, developed by the authors of the research. Participants, corporate managers of middle education level, were divided into groups of four or five people. The training lasted one day. Participants answered an instrument to measure skills and attitudes related to Therapeutic Listening before the start of training, one month and three months after training. According to the results, the scores of the subscales Listening Attitudes $(p<0.001)$ and Listening skills $(p<0.001)$ increased in both the first and the third month after the training.

The study $A 10^{(31)}$ used the dramatization of consultation and counseling as a way of teaching Therapeutic Listening. The participants were randomly allocated into three groups of training to practice communication skills. One group received 14 hours of training. The other two groups had the same kind of training of the first group, however, the training was repeated, so that one group received 28 hours and the other group 42 hours of course. The results suggest that students used the Therapeutic Listening after different periods of training $(p=0.74)$. Nevertheless, longer training time resulted in increased expression of feelings by the participants, so they reported more emotions in the post-test than in the pre-test $(p<0.05)$. Still, the result of the Recorded Information versus Interaction Time was in favor of the trained group of 42-hour course, which had the highest average recall of information from the students $(p<0.01)$.

Researches on the effectiveness of Therapeutic Listening Visits as intervention accounted for $27 \%$ of the publications (A7, A11, A12 and A14). The study $A 7^{(28)}$ was an experimental study that compared the health outcomes of mothers and their newborns, which were divided into three groups: Support Health Visitor (SHV) Community Group Support (CGS) and control group. For the SHV a year of monthly Therapeutic Listening visits at Home was offered. CGS consisted of local community groups that offered services to women and their babies (daycare center, breastfeeding advice, among others). In the control group, they offered routine health services. According to the results, there were no differences that could not be attributed to chance in the primary outcomes (maternal depression, injury in the child and maternal smoking). Regarding secondary outcomes, in relation to CGS and control groups, women's SHV reduced the number of doctor visits due to the child (mean difference $=-0.21,95 \% \mathrm{Cl}-0.38$ to -0.04 ) increased use of services offered by health care providers and social workers (mean difference $=0.13,95 \% \mathrm{Cl} 0.04$ to 0.21 ) and had less concern about the child's development (speech: mean difference $=0.43,95 \% \mathrm{Cl} 0.22$ to 0.84 ; Alimentation: mean difference $=0.65,95 \% \mathrm{Cl} 0.42$ to 1.00 ). 
The study $A 11^{(32)}$, women with depressive symptoms received up to six Therapeutic Listening visits at home. The variables investigated were: depression, life satisfaction and acceptability of treatment. Participants were interviewed at three different moments: pre-visit (0 months), post-visit ( 2 months after the visits) and follow-up (five months after of the visits had started or three months after the last visit). According to the results, during the five months between the pre and post-visit, the mean scores of all measures of depression decreased $(p<0.0001 ; p=0.03$; $p=0.004)$. $63.2 \%$ of women were considered recovered and two thirds showed clinically significant improvement. Regarding life satisfaction, the results indicated positive change in this variable over time $(p=0.01)$. The average of the instrument used to measure the acceptability of treatment was 5.7, indicating that women considered the Therapeutic Listening Visits as very useful.

The study $\mathrm{A} 12^{(33)}$, women diagnosed with postpartum depression were randomly assigned to two groups: in one group the participant received an antidepressant $(n=129)$ and in the other, the participant received the Therapeutic Listening Visits $(n=125)$. Initially, a series of four visits were offered throughout four to six weeks. On the fourth visit, the professional and the woman reviewed the progress and decided whether they should finalize visits or not (women could go to the antidepressants group or alternative services), or would perform a second set of four visits. In four weeks, the females from the antidepressants group were more than twice as likely to be better when compared to the ones who had received Therapeutic Listening Visits (odds ratio $=3.4 ; 95 \% \mathrm{Cl} 1.8$ to 6,$5 ; \mathrm{p}<0.001$ ). With 18 weeks of treatment, the proportion of improvement in women was $11 \%$ higher in the group of antidepressants, however, there was no clear benefit of one group over another (Odds Ratio $=1.5 ; 95 \% \mathrm{Cl} 0.8$ to 2.6; $\mathrm{p}=0.19$ ). Interviews with women revealed a preference for Therapeutic Listening Visits, however, they recognized that antidepressants could be necessary.

The study $A 14^{(35)}$ evaluated the feasibility, acceptability and effectiveness of Therapeutic Listening offered to mothers of premature infants hospitalized in a neonatal intensive care. The researchers' hypothesis was that the Therapeutic Listening was associated with the clinical improvement of the mother, as well as improved self-perceived quality of life. The intervention was performed by a neonatal nurse, who made six visits to each participant. Each visit lasted 4560 minutes and was held in a hospital room that guarantee privacy to women. The variables investigated were: depression, anxiety, quality of life and acceptability of visits. After conducting the visits, symptoms of depression $(p<0.001)$ and anxiety $(p<0.005)$ declined significantly. Regarding quality of life, the results suggest a significant improvement in this variable $(p<0.001)$. Most women who received visits $(91.3 \%)$ rated them as excellent.

Among the included studies, only three (20\%) used a qualitative approach (A8, A13 and A15). Through in-depth interviews, which allows the exploration of one or more themes with greater flexibility, unlike what happens in the case of the use of questionnaires or a fully structured interview, the $A 8^{(29)}$ and $A 13^{(34)}$ studies have attempted to explore the experiences of women with postpartum depression who received Therapeutic Listening Visits. According to the results of the A8 study ${ }^{(29)}$, the factors that made a positive experience of the visits were: to agree with the medical model for postpartum depression, having a good relationship with the professional who conducts the visits, having the opportunity to make choices and the fact that the visits are developed as a clear and flexible process. The findings of the study $\mathrm{A} 13^{(34)}$ indicated that all participants reported that the Therapeutic Listening Visits were beneficial, although many of them were in need of additional intervention to control depressive symptoms. Still, the effectiveness of visits appears to be linked to the causes of depression, the way visits are conducted and by whom they are performed. The researchers concluded that women with postpartum depression consider the Therapeutic Listening Visits as something useful, but insufficient for the treatment of depression.

In the study $\mathrm{A} 15^{(36)}$, through interviews, students in a course on counseling were invited to reflect on personal experiences lived during the first year of the course. One of the themes that emerged during the interviews was about learning to listen, that is, becoming aware of what you are doing when you are listening to. Some participants said they used to filter what people said from his/ her own personal experiences. Another aspect revealed was about to listen to how relationships were developed with other people. Still, participants referred to the revelation of otherness, that is, listening as a revelation of the realities of others. Finally, graduate students spoke about the difference between being able to listen and receiving information only.

In the study $A 1^{(22)}$, psychology students and psychotherapists participated in the research in order to observe whether prior information about the patient can influence the Therapeutic Listening process. Half of the participants in each group (students and professionals) received only the instructions for participation in the study, the other half, in addition to the instructions, also received some information about the patient. A real therapeutic tape-recorded interview was used as stimulus material. After hearing the statements of the patient, the participant should answer the following question: What did the patient tell you? According to the results, most therapists have more interpretive responses than students $(0.01<p<0.05)$, however, analysis of the possible effect of clinical information about the patient did not produce significant differences.

To conduct the study $A 9^{(30)}$, supervisors responded an instrument on attitudes and skills for listening. The subordinates responded two instruments, one on their working conditions and the other about their reactions to 
psychological stress. According to the findings, the subordinates who worked with supervisors had high scores of skills and attitudes for Therapeutic Listening, they reported more favorable reactions to psychological stress (men: $p=0.47$; women: $p=0.004$ ) and greater control at work (male: $p=0.026$; female: $p=0.007$ ).

In the study $\mathrm{A}^{(24)}$ a series of experiments were performed in order to observe whether, in the process of Therapeutic Listening, the way how answers are formulated can interfere with affective reaction of patients. Two types of answers were studied. In type A, responses are neutral or imply the existence of alternative interpretations, such as to how the patient react about a situation. The researchers found that, paraphrasing the statements of the patient in order to accept the interpretation regarding alternative interpretations about a given situation, the patient may present less intense levels of anger $(p<0.0001)$ and depression $(p=0.0105)$ than if statements are used in a way that assumes the accuracy of the interpretations of the patient.

\section{DISCUSSION}

Despite the recognized therapeutic value of listening ${ }^{(14)}$, primary studies on this topic are scarce, after all, only 15 publications were found in the scientific literature related to the purpose of this review. However, it is noteworthy that, although scarce, most of the studies reported levels of evidence that allow reliability in using their results ${ }^{(39)}$.

It can be observed that a common point among most of the included studies, is the acknowledgment of skills on the part of health professionals, to develop a process of effective listening. There are a number of ways to listen. One of them, for example, is when you listen to a friend or family situation in which they are invited to offer their points of view while listening with sympathy or makes comments that aim to calm who is heard ${ }^{(40)}$. Another way would be when the individual seeks a professional to listen and advise or provide accurate information about their concerns, for example, when looking for a lawyer for legal issues. In this case, a specialized consulting is provided and the information is transmitted. A third way of listening, distinct from the other two, involves the absorption of the narrative of a person without offering advice or information, so that, upon listening reports of diseases or life experiences from a psychological point of view, such an attitude is therapeutic ${ }^{(40)}$.

The Nursing Interventions Classification ${ }^{(9)}$ presents the intervention Listening Visits, which was created in the UK to circumvent barriers related to accessibility and acceptability of treatment for depression in women from ethnic minorities and low income ${ }^{(41-42)}$. This intervention consists of using techniques from the non-directive counseling as exploration of a problem through the Therapeutic Listening and resolving in collaboration with the patient ${ }^{(32)}$. Listening Visits presents itself as an effective activity in reducing the rates of anxiety and depression in women with postpartum depression or mothers of premature babies ${ }^{(28,32,35)}$. For such women, this intervention was beneficial, since it was presented as an opportunity to talk and concentrate on their own feelings and circumstances ${ }^{(34)}$. According to researches, as often, the individual just needs someone to listen so he/she can arrange and organize their own experience and, even though the solution to their problems seem distant or even impossible, simply talking about it causes an immediate relief sensation ${ }^{(43)}$, which prevents the individual to be without psychological structure by experiencing a tension level above his/her limit ${ }^{(11)}$. However, for the process of listening to develop satisfactorily, it is important that the professional has skills to provide emotional and practical support to the patient, so he/she can identify him/herself with the situation and feel able to trust this professional providing care ${ }^{(29,34)}$.

The Therapeutic Listening skill, an important component of the communication process, involves understanding of what the other person says and feels and then communicating that understanding back to it ${ }^{(23)}$. The health team can and should provide the patient with quality care, however, for this to occur it is necessary to assimilate communication skills ${ }^{(44)}$ which are not acquired empirically or with time, but only with adequate education $^{(15)}$. In this context, it is relevant to the study of methods that can assist in the teaching of Therapeutic Listening. According to the studies of this review that investigated the effectiveness of training on listening skills, activities like dramatization ${ }^{(25,27,31)}$, readings, practical activities, discussions about the process of listening, lectures ${ }^{(23,26)}$ between others, can contribute to the teaching of this communication technique.

The lack of ability to practice Therapeutic Listening can, for example, depend on how the statements are paraphrased to the patient, generating feelings of anger and depression ${ }^{(24)}$. Knowing how to therapeutically listen can have a positive impact on the one listened, for example, when assisting them in the formulation of more favorable reactions to psychological stress ${ }^{(30)}$. Finally, the process of listening requires becoming aware of what one is doing when he/she is listening, and understanding that there is a difference between listening and only receiving information ${ }^{(36)}$.

\section{CONCLUSION}

Based on the presented results, we can conclude that most of the included studies for this review have strong to moderate level of evidence, allowing reliability of their results and, although addressing different aspects related to Therapeutic Listening, they have in common the recognition of the need for skills on the part of health professionals, to develop a process of effective listening. 
Among the 15 included studies, five addressed the effect of training on the skills of Therapeutic Listening, four studied the efficacy of listening as an intervention, three explored the experiences lived of the subjects related to listening, and three discussed various aspects of listening (the influence of prior information about the patient at the Therapeutic Listening process, the relationship between attitudes and listening skills of supervisors and working conditions of psychological stress reactions of their subordinates, and finally, how to formulate their answers in the process of therapeutic listening, which can influence the affective reaction of patients).

One aspect that may have interfered with the results concerns the electronic search that was conducted in five databases with the descriptors presented. The study, in

\section{REFERENCES}

1. Haes $\mathrm{H}$, Teunissen S. Communication in palliative care: a review of recent literature. Curr Opin Oncol. 2005;17(4):345-50.

2. Skilbeck J, Payne S. Emotional support and the role of Clinical Nurse Specialist in palliative care. J Adv Nurs. 2003;43(5):521-30.

3. Salimena AMO, Martins BR, Melo MCSC, Bara VMF. Como mulheres submetidas à quimioterapia antineoplásica percebem a assistência de enfermagem. Rev Bras Cancerol. 2010;56(3):331-40.

4. Benjamim A. A entrevista de ajuda. São Paulo: Martins Fontes; 1983.

5. Filgueiras SL, Deslandes SF. Evaluation of counseling activities: analysis of a person-centered prevention perspective. Cad Saúde Pública. 1999;15 Suppl 2:121-31.

6. Lazure H. Viver a relação de ajuda: abordagem e prática de um critério de competência da enfermeira. Lisboa: Luso Didacta; 1994

7. Stefanelli MC. Estratégias de comunicação terapêutica. In: Stefanelli MC, Carvalho EC. A comunicação nos diferentes contextos da Enfermagem. 2a ed. Barueri: Manole; 2012. p. 77-109.

8. Mucchelli R. A entrevista não-diretiva. São Paulo: Martins Fonte; 1978.

9. Bulechek GM, Butcher HK, Dochterman JM, Wagner CM. Nursing Interventions Classification (NIC). 6th ed. St. Louis: Elsevier; 2013.

10. Watanuki MF, Tracy R, Lindquist R. Therapeutic listening. In: Tracy R, Lindquist R. Complementary alternative therapies in nursing. New York: Springer; 2006. p. 45-55.

11. Souza RC, Pereira MA, Kantorski LP. Therapeutic listening: an essential instrument in nursing care. Rev Enferm UERJ. 2003;11(1):92-97. addition to summarizing the evidence regarding the use of Therapeutic Listening as a health intervention, provides a direction for nurses and other health professionals to think about the use of such intervention in their clinical practice, as this presents itself as a beneficial intervention for the welfare of the individual. However, it is important to pay attention to the need for training of health professionals to perform this activity, since the lack of skills to conduct the Therapeutic Listening can cause harm to the patient. Further studies, especially experimental, should consider the theoretical aspects that support this intervention, they will explore in greater depth the effects of Therapeutic Listening applied in the context of health and meet potential patient conditions that may influence the achievement of expected results with this technique.

12. Bermejo Higuera JC. La escucha activa em cuidados paliativos. ARS Méd (Santiago). 2005;(11):119-36.

13. Brusamarello T, Capistrano FC, Oliveira VC, Mercês NNA, Maftum MA. Cuidado a pessoas com transtorno mental e familiares: diagnósticos e intervenções a partir da consulta de enfermagem. Cogitare Enferm. 2013;18(2):245-52.

14. Fassaert T, Dulmen S, Schellevi F, Bensing J. Active listening in medical consultations: development of the Active Listening Observation Scale (ALOS-global). Patient Educ Couns. 2007;68(3):258-64.

15. Araújo MMT, Silva MJP. The knowledge about communication strategies when taking care of the emotional dimension in palliative care. Texto Contexto Enferm. 2012;21(1):121-9.

16. Santos L, Torres HC. Educational practices in diabetes mellitus: understanding the skills of health professionals. Texto Contexto Enferm. 2012;21(3):574-80.

17. Lima DWC, Silveira LC, Vieira AN. Listening in the treatment of psychological stress an integrative review. J Nurs UFPE on line [Internet]. 2012 [cited 2014 June 17];6(9):2273-80. Available from: http://www.revista.ufpe.br/revistaenfermagem/index.php/revista/article/view/2632/pdf_1479

18. Roman AR, Friedlander MR. Revisão integrativa de pesquisa aplicada à enfermagem. Cogitare Enferm. 1998;3(2):109-12.

19. Whittemore R, Knafl K. The integrative review: updated methodology. J Adv Nurs. 2005;52(5):546-53.

20. Mendes KDS, Silveira RCCP, Galvão CM. Integrative literature review: a research method to incorporate evidence in health care and nursing. Texto Contexto Enferm. 2008;17(4):758-64.

21. Ursi ES, Galvão CM. Perioperative prevention of skin injury: an integrative literature review. Rev Latino Am Enfermagem. 2006;14(1):124-31. 
22. Sommer GR, Mazo B, Lehner GFJ. An empirical investigation of therapeutic "listening". J Clin Psychol. 1955;11(2):132-6.

23. Olson JK, Iwasiw CL. Effects of a training model on active listening skills of post-RN students. J Nurs Educ. 1987;26(3):104-7.

24. Nugent WR, Halvorson $\mathrm{H}$. Testing the effects of active listening. Res Soc Work Pract. 1995;5(2):152-75.

25. Lisper $\mathrm{H}$, Rautalinko E. Effects of a six hour training of active listening. Scand J Behav Ther. 1996; 25(3-4):117-25.

26. Kubota S, Mishima N, Ikemi A, Nagata S. A research in the effects of active listening on corporate mental health training. J Occup Health. 1997;39(4):274-9.

27. Kubota S, Mishima N, Nagata S. A study of the effects of active listening on listening attitudes of middle managers. J Occup Health. 2004;46(1):60-7.

28. Wiggins M, Oakley A, Roberts I, Turner H, Rajan L, Austerberry $\mathrm{H}$, et al. The Social Support and Family Health Study: a randomised controlled trial and economic evaluation of two alternative forms of postnatal support for mothers living in disadvantaged inner-city areas. Health Technol Assess. 2004;8(32):iii,ix-x,1-120.

29. Shakespeare J, Blake F, Garcia J. How do women with postnatal depression experience listening visits in primary care? A qualitative interview study. J Reprod Infant Psychol. 2006;24(2):149-62.

30. Mineyama S, Tsutsumi A, Takao S, Nishiuchi K, Kawakami $\mathrm{N}$. Supervisors' attitudes and skills for active listening with regard to working conditions and psychological stress reactions among subordinate workers. J Occup Health. 2007;49(2):81-7.

31. Rautalinko E, Lisper HO, Ekehammar B. Reflective listening in counseling: effects of training time and evaluator social skills. Am J Psychother. 2007;61(2):191-209.

32. Segre LS, Stasik SM, O'Hara MW, Arndt S. Listening visits: an evaluation of the effectiveness and acceptability of a home-based depression treatment. Psychother Res. 2010;20(6):712-21.

33. Sharp DJ, Chew-Graham C, Tylee A, Lewis G, Howard L, Anderson I, et al. A pragmatic randomised controlled trial to compare antidepressants with a community-based psychosocial intervention for the treatment of women with postnatal depression: the RESPOND trial. Health Technol Assess. 2010;14(43):iii-iv, ix-xi, 1-153.
34. Turner KM, Chew-Graham C, Folkes L, Sharp D. Women's experiences of health visitor delivered listening visits as a treatment for postnatal depression: a qualitative study. Patient Educ Couns. 2010;78(2):234-9.

35. Segre LS, Chuffo-Siewert R, Brock RL, O'Hara MW. Emotional distress in mothers of preterm hospitalized infants: a feasibility trial of nurse-delivered treatment. J Perinatol. 2013;33(12):924-8.

36. Lee B, Prior S. Developing therapeutic listening. Br J Guid Couns. 2013;41(2):91-104.

37. Polit DF, Beck CT. Essentials of nursing research: appraising evidence for nursing practice. 8th ed. Philadelphia: Lippincott Williams \& Wilkins; 2014. Quantitative research design; p. 149-75.

38. Melnyk BM, Fineout-Overholt E. Evidence based practice in nursing \& healthcare: a guide to best practice. 2th ed. Philadelphia: Lippincot Williams \& Wilkins; 2011. Making the case for evidence-based practice; p.3-24.

39. Polit DF, Beck CT. Essentials of nursing research: appraising evidence for nursing practice. 8th ed. Philadelphia: Lippincott Williams \& Wilkins; 2014. Fundamentals of evidencebased nursing practice; p.20-39.

40. Jones AC, Cutcliffe JR. Listening as a method of addressing psychological distress. J Nurs Manag. 2009;17(3):352-8.

41. Segre LS, McCabe JE, Stasik SM, O'Hara MW, Arndt S. Implementation of an evidence-based depression treatment into social service settings: the relative importance of acceptability and contextual factors. Adm Policy Ment Health. 2012;39(3):180-6.

42. Levy LB, O'Hara MW. Psychotherapeutic interventions for depressed, low-income women: a review of the literature. Clin Psychol Rev. 2010;30(8):934-50.

43. Miranda CF, Miranda ML. Construindo a relação de ajuda. 10a ed. Belo Horizonte: Crescer; 1996.

44. Bertachini L. A comunicação terapêutica como fator de humanização da Atenção Primária. Mundo Saúde. 2012;36(3):507-20. 